\title{
Protective Potential of Aqueous Leaf extract of Vernonia amygdalina in Cyclophosphamide - Induced Myelotoxicity
}

\author{
Ikeh, Chibueze Kennedy ${ }^{1}$, Ikeh, Patricia Erebi ${ }^{2}$, Ezike, Chioma Adaobi ${ }^{3}$, \\ 1. Department of Pharmacology, College of Health Sciences, Niger Delta University, Wilberforce Island, \\ Bayelsa State, Nigeria. \\ 2. Department of Chemical Pathology, College of Health Sciences, Niger Delta University Wilberforce Island, \\ Bayelsa State, Nigeria. \\ 3. Department of Pharmacology and Toxicology, Faculty of Pharmaceutical sciences, University of Nigeria, \\ Nsukka.
}

\begin{abstract}
Cyclophosphamide $(C P)$ is among the most widely used alkylating anti-cancer agents in chemotherapy. Myelotoxicity is one of its dose-limiting adverse effects. The aim of the present study, therefore, was to investigate the possible protective potential of Vernonia amygdalina (VA) aqueous leaf extract in CPinduced myelotoxicity through evaluation of haematological parameters, glutathione (GSH), lipid peroxidation, antioxidant enzymes (superoxide dismutase (SOD), and catalase(CAT)) as well as histopathological examination of the kidney and liver sections of rats. Outcome was compared with that expressed by MESNA. Administration of $C P$ in a single dose $(200 \mathrm{mg} / \mathrm{kg}$, i.p. $)$ significantly $(P<0.01)$ decreased $R B C s, W B C s$ and platelets counts. In addition, $C P$ produced a significant $(P<0.01)$ reduction of all biochemical parameters assayed as well as observable disruption of liver and kidney tissue architectures. Pretreatment of animals with $V A(250 \mathrm{mg} / \mathrm{kg}$, per os) daily for 10 consecutive days significantly $(P<0.01)$ ameliorated the changes in haematological and biochemical parameters as well as histopathological changes induced by CP when compared to the CP-treated group. Conclusively, Vernonia amygdalina (VA) aqueous leaf extract could have protective potential against $C P$-induced myelotoxicity.
\end{abstract}

Key-words: Cyclophosphamide; MESNA; Myelotoxicity, Vernonia amygdalina.

\section{INTRODUCTION}

It is a well-known fact that neoplasms are deleterious and reduce quality of life. Cyclophoshpamide (CP) has been well documented to be effective in management of many human malignancies in order to improve quality of life ${ }^{[1-4]}$. Many clinicians have continued to use CP either alone or in combination with other agents in cancer chemotherapy due to its efficacy despite its notable adverse effects which include: myelotoxicity, haemorrhagic cystitis, nausea, vomiting, alopaecia, nephrotoxicity, immunotoxicity, mutagenicity, carcinogenicity and teratogenicity. ${ }^{[5-6]}$

Considering the inevitable cytostatic toxicity of $\mathrm{CP}$, numerous researches are being carried out to find methods to abolish, or at least ameliorate the toxicity it presents ${ }^{[7-9]}$. The development of cytoprotection is the most pharmacologically attractive method of diminishing the CP toxicity. The design of chemoprotectants development has been proven to be essential during antineoplastic chemotherapy. Chemoprotectants are compounds providing tissue-specific cytoprotection, without compromising the desired antitumour efficacy or contributing an additional own toxicity that might jeopardise the effects of adequate chemotherapy [7].

A sulfhydryl-containing agent, MESNA (Sodium-2-mecarptoethane sulfonate), has long been used in detoxifying and ameliorating specifically the urotoxic effects of $\mathrm{CP}$ and other oxazaphosphorines [10-11]. However, there is no evidence of myeloid protection by this agent. Again, its own side effects are equally disturbing and needs to be addressed ${ }^{[12]}$.

Natural products have recently gained acceptance and have continued to gain grounds in therapeutics due to their acclaimed efficacy in management of many ailments with little or no side effects when used appropriately. They are also readily available depending on the region and geographical distribution. Many natural products have been widely reported to ameliorate at varying degrees the side effects of oxazophosphorines e.g. cyclophosphamide and ifosphamide ${ }^{[9]}$. 
Numerous studies have shown that Vernonia amygdalina is capable of detoxifying the body owing to its antioxidant properties thereby protecting the essential organs like the liver, kidney, heart, etc [13-15]. $V$. amygdalina Del, commonly called bitter leaf, is a perennial shrub of between $2-5 \mathrm{~m}$ in height that is commonly found in the tropics. It belongs to the family Asteraceae. The leaves are greenish and elliptic in shape with about $6 \mathrm{~mm}$ length. It characteristic odor and bitter taste ${ }^{[16]}$. The plant has been domesticated in many parts of West Africa, [17]. It is known as 'Chusar-doki' in Hausa, 'Ewuro' in Yoruba, 'Onugbu' in Igbo, 'Ityuna' in Tiv, 'Oriwo' in Edo, 'Etidot' in Ibibio, and 'Grawa' in Amharic, ${ }^{[18]}$. V. amygdalina is drought tolerant though it grows better in a humid environment.

The leaves have long been found useful in traditional folk medicine as antimalarial, antimicrobial, anthelmintics, antidiabetic, and anticancer ${ }^{[19-20]}$.

The present study investigated for the first time the protective potential of $V$. amygdalina in CP-induced myelotoxicity in albino Sprague-Dawley rats.

\subsection{Extract Preparation}

\section{MATERIALS AND METHODS}

Leaves of $V$. amygdalina were sourced from Abakpa Nike Enugu, and were identified at the Department of Pharmacognosy, Faculty of Pharmacy, Niger Delta University, Bayelsa state, Nigeria. A known weight of freshly collected $V$. amygdalina $(552.5 \mathrm{~g})$ was macerating for 12 hours in distilled water and blended using electric blender, after which it was filtered properly. The filtrate was lyophilized using Yorco $^{\mathrm{TM}}$ Lyophylizer (PVT Industries, China) to yield dry $23.87 \mathrm{~g} \mathrm{(4.32 \% )} \mathrm{of} \mathrm{V.} \mathrm{amygdalina} \mathrm{extract.}$

\subsection{Animals}

Out-bred mature Sprague-Dawley albino male rats $(130 \mathrm{~g}-200 \mathrm{~g})$ were used. They were procured from the animal house unit of the department of Pharmacology, College of Health Sciences, Niger Delta University, Wilberforce Island, Bayelsa state and housed in a well ventilated room at the same environment at room temperature of about $280 \mathrm{C} \pm 3$ using standard rat cages. The animals were allowed to acclimatize for two (2) weeks and fed with standard rat chow (Vital feed Nigeria, Plc) and water provided ad libitum. They were placed under 12:12 hr light dark cycle. The entire experimental protocols were performed in accordance with the Institutional Animal Ethical Committee (IAEC) in line with the directions of the committee for the purpose of control and supervision of experiments on animals (CPCSEA) in the Niger Delta University, Wilberforce Island, Bayelsa state, Nigeria.

\subsection{Chemicals and Reagents}

Cyclophosphamide (CYCLOXAN ${ }^{\circledR} 500 \mathrm{mg}$ ) and Sodium - 2 - Mecarptoethane sulfonate (MESNA) (BIOCHEM Pharmaceutical Industries Ltd.,Mumbai, India), catalase, Supraoxide dismutase and glutathione commercial kits (Sigma Aldrich St Louis, USA) were used for biochemical assay. All other reagents used were of standard analytical grade.

\subsection{Induction of CP-induced Toxicity}

Cyclophosphamide (CYCLOXAN $500 \mathrm{mg}$ ) and MESNA were suspended in normal saline before administering to the test animals at the dose of $200 \mathrm{mg} / \mathrm{kg}$ and $67 \mathrm{mg} / \mathrm{kg}$ body weight respectively.

The CP and MESNA were given intraperitoneally (i.p) whereas extract of V. amygdalina (VA) was given orally (per os) using gavage. The same dose schedule of $\mathrm{CP}(200 \mathrm{mg} / \mathrm{kg})$ was given to all the groups that received CP. The animals were divided into five (5) equal groups of six (6) rats each, $(n=6)$.

Group 1= CP group (non-treated control) rats received a single i.p administration of $\mathrm{CP}$ on the tenth day after oral gavage of normal saline for ten consecutive days.

Group 2 = MESNA+CP group: received normal saline for ten consecutive days before a single i.p dose of MESNA at $67 \mathrm{mg} / \mathrm{kg}$ on the tenth day after which single dose of $\mathrm{CP}$ was administered within five minutes interval on the same day.

Group 3 = VA+CP group: received $250 \mathrm{mg} / \mathrm{kg}$ V. amygdalina orally for ten consecutive days followed by i.p administration of $\mathrm{CP}$ on the tenth day.

Group 4 = VA alone group: received only $250 \mathrm{mg} / \mathrm{kg}$ V. amygdalina orally for ten consecutive days. Group $5=$ Naive control rats received only normal saline orally for ten consecutive days. The dosing procedure was performed in such a way that the entire rats in all the groups could be sacrificed on the $11^{\text {th }}$ day. The LD50 of $V$. amygdalina extract was found to be $1500 \mathrm{mg} / \mathrm{kg}$ based on our pilot study. 


\subsection{Blood sample collection}

Prior to death on the $11^{\text {th }}$ day, blood sample was collected through the ophthalmic venous plexus located in the orbital sinus of the rats with the aid of micro-capillary pipette ${ }^{[21]}$, as modified by Rilley (1960) [22]. About $1 \mathrm{ml}$ of blood collected from each of the rats was introduced into a clean labeled sample bottle containing $1 \mathrm{mg}$ Na-EDTA powder and mixed mildly to avoid clotting.

\subsection{Haematological test}

To determine the level of myelosuppression, the blood sample, immediately upon collection was analyzed using an automated dialyzer machine. Model No: Sysmex kx-21n 3 - part differential analyzer (Sysmex Corporation, Kobe, Japan).

\subsection{Biochemical analysis}

After the ten days experimental period, animals were sacrificed by means of cervical dislocation on the eleventh day (i.e. within 24hrs). The kidney and liver was harvested for onward biochemical investigation with some parts preserved using $10 \%$ buffered formalin for histopathological studies.

\subsubsection{Analysis of glutathione (GSH)}

The serum glutathione was estimated according to the method described by Sedlak and Lindsay, 1968

[23]. To $1 \mathrm{ml}$ of the sample suspension $(1 \mathrm{mg}$ protein/ml), $1 \mathrm{ml}$ of $10 \%$ TCA (Trichloroacetate) containing 1 mM EDTA was added. The protein precipitate was separated by high speed centrifugation at $2500 \mathrm{rpm}$ for 10 min. About $1 \mathrm{ml}$ of supernatant was treated with $0.5 \mathrm{ml}$ of Ellmans reagent and $3 \mathrm{ml}$ of phosphate buffer $(0.2$, $\mathrm{pH}$ 7.4). The absorbance was read at $412 \mathrm{~nm}$ using spectrophotometer.

\subsubsection{Superoxide dismutase analysis}

A method originally described by Misra and Fridovich, 1972, ${ }^{[24]}$ as reported by Magwere, 1997 [25] was employed. The homogenate was supplemented with $2.5 \mathrm{ml}$ of carbonate buffer, followed by equilibration at room temperature; $0.3 \mathrm{ml}$ of $0.3 \mathrm{nM}$ adrenaline solution was then added to the reference and the test solution, followed by mixing and reading of absorbance at $420 \mathrm{~nm}$.

\subsubsection{Catalase assay}

Activity of catalase in urinary bladder was determined according to procedure of Sinha, (1972) [26]. This method is based on the reduction of dichromate in acetic acid to chromic acetate when heated in the presence of $\mathrm{H}_{2} \mathrm{O}_{2}$, with the formation of perchromic acid as an unstable intermediate. The chromic acetate so produced is measured. Absorbance was read at $480 \mathrm{~nm}$ within 30-60 seconds against distilled water.

\subsubsection{Malondialdehyde (MDA) Assay}

The MDA assay method of Hunter, $1963^{[27]}$ as modified by Gutteridge and Wilkins, $1982^{[28]}$ was adopted. Malondialdehyde (MDA), a product of lipid peroxidation, when heated with 2- thiobarbituric acid (TBA) under acid conditions forms a pink colored product which has a maximum absorbance of $532 \mathrm{~nm}$. The urinary bladder homogenate was supplemented with I $\mathrm{g}$ of TBA in $100 \mathrm{ml}$ of $0.2 \% \mathrm{NaOH}$ and $3 \mathrm{ml}$ of glacial acetic acid, thoroughly mixed and incubated in boiling water bath for 15 minutes, then allowed to cool after which they were centrifuged. Absorbance was read at $532 \mathrm{~nm}$ and the results expressed as nanomoles MDA/mg wet tissue.

\subsection{Clinical Examination for Haematuria}

Clinical examination for presence of haematuria was carried out by placing white clean cardboard paper on the floor of the rat cages. Presence of frank blood mixed with urine was observed after $24 \mathrm{hrs}$ of CP administration.

\subsection{Histopathological Examination}

Small portions of kidney and liver was fixed in $10 \%$ buffered formalin, processed and embedded in paraffin wax. Sections of about $5 \mu \mathrm{m}$ were made and stained with routine haematoxylin and eosin (H \& E) for examination by light microscopy.

\subsection{Statistical Analysis}

Data obtained were analyzed using One-way Analysis of Variance (ANOVA) in SPSS version 15.0 and subjected to LSD and Duncan post-hoc test. Significant difference between means of treated and control were accepted at $P<0.01$. Data were expressed as Mean \pm SEM. 
III. RESULTS

\subsection{Effects of extracts on CP-induced urotoxicity}

\subsubsection{Effects of extract on glutathione}

The CP $(200 \mathrm{mg} / \mathrm{kg})$ treated animals showed a significant $(P<0.01)$ decrease in GSH content in the serum compared to naive group. The GSH values for animals that received MESNA+CP and $250 \mathrm{mg} / \mathrm{kg}$ $\mathrm{VA}+\mathrm{CP}$ were significantly $(P<0.01)$ higher than those of CP alone (TABLE 1$)$.

\subsubsection{Effects of extracts on SOD Activity.}

Superoxide dismutase activity was significantly reduced $(P<0.01)$ in $\mathrm{CP}$ treated animals when compared with naïve (control) animals. Animals that were given MESNA+CP, VA+CP and VA only showed a significant $(P<0.01)$ increase in SOD activity than CP treated group (TABLE 1$)$.

\subsubsection{Effects on catalase activity}

Catalase activity in the serum of CP-treated animals was significantly lower $(P<0.01)$ than naïve (control) animals that received only normal saline. Animals that were given MESNA+CP, VA+CP and VA only showed a significant $(P<0.01)$ increase in catalase activity than CP treated group (TABLE 1$)$.

\subsubsection{Effects of extracts on lipid peroxidation (LPO)}

Lipid peroxidation (LPO) was measured as the amount of thiobabituric acid reactive substances (TBARS) in the urinary bladder. The results were expressed as malondialdehyde (MDA) formed using molar extinction coefficient of $1.56 \times 10^{5} \mathrm{M} / \mathrm{cm}$. TABLE 2 presented CP-treated animals showing significantly high levels of LPO values $(P<0.01)$ compared to naive (control). Animals treated with, MESNA+CP, VA+CP and VA only, showed LPO values that were similar but significantly lower $(P<0.01)$ than in $\mathrm{CP}$ treated animals

\subsection{Effect on haematological parameters.}

The CP-treated rats depicted values of total RBCs count, leukocyte count, absolute neutrophil and lymphocyte counts that were significantly $(P<0.01)$ lower than those of naïve (control) rats. Animals that received MESNA+CP had significantly $(P<0.01)$ higher values than the $\mathrm{CP}$ treated animals. However, these values were significantly lower $(P<0.01)$ than the control group. Values of total RBCs count, leukocyte count, absolute neutrophil and lymphocytes for $250 \mathrm{mg} / \mathrm{kg}$ $\mathrm{VA}+\mathrm{CP}$ and $250 \mathrm{mg} / \mathrm{kg}$ VA alone groups were significantly $(P<0.01)$ higher than in CP treated animals (TABLE 3$)$.

\subsection{Effect on platelet count, absolute basophils and eosinophils}

Animals that received only CP had significantly $(P<0.01)$ low values of platelet than those of control animals. The groups that received MESNA+CP, $250 \mathrm{mg} / \mathrm{kg} \mathrm{VA}+\mathrm{CP}, 250 \mathrm{mg} / \mathrm{kg} \mathrm{VA}$ alone indicated significantly $(P<0.01)$ higher platelet counts than CP-treated group.

The absolute basophils and eosinophils result depicted no significant change for all the groups (TABLE 3 ).

Table 1: Effects of $V$. amygdalina on GSH, SOD and Catalase Activities in CP-induced Toxicity

\begin{tabular}{|c|c|c|c|c|}
\hline \multirow[t]{2}{*}{ Treatment } & \multirow[t]{2}{*}{ Dose $\mathrm{mg} / \mathrm{kg}$} & \multicolumn{3}{|c|}{ Reduced glutathione \& antioxidant enzymes } \\
\hline & & GSH nM/g tissue & SOD $\mu M / m g$ tissue & Catalase nM/mg tissue \\
\hline CP Alone & 200 & $1.00 \pm 0.10^{\mathrm{b}}$ & $2.42 \pm 0.31^{\mathrm{b}}$ & $3.01 \pm 0.31^{\mathrm{b}}$ \\
\hline MESNA+CP & 67 & $4.77 \pm 0.38 *^{\mathrm{a}}$ & $9.49 \pm 0.65 *^{\mathrm{a}}$ & $13.67 \pm 0.51 *^{\mathrm{a}}$ \\
\hline $\mathrm{VA}+\mathrm{CP}$ & 250 & $5.16 \pm 0.29$ *a & $10.26 \pm 0.33^{* a}$ & $15.27 \pm 0.54 * \mathrm{a}$ \\
\hline VA Alone & 250 & $5.78 \pm 0.46 *^{\mathrm{a}}$ & $10.38 \pm 0.58 * \mathrm{a}$ & $15.31 \pm 0.81 *^{\mathrm{a}}$ \\
\hline $\begin{array}{l}\text { Naïve Control } \\
\text { (Normal Saline) }\end{array}$ & $0.2 \mathrm{ml} / 100 \mathrm{~g}$ & $5.28 \pm 0.45^{* \mathrm{a}}$ & $9.79 \pm 0.32 * \mathrm{a}$ & $14.92 \pm 0.33 * \mathrm{a}$ \\
\hline
\end{tabular}

One-way ANOVA followed by post-hoc LSD and Duncan was adopted.

$\mathrm{LSD}=$ Means in the same column with asterisks $(*)$ indicate significant different $P<0.01$, compared to CP treated animals. Duncan= Means in the same column with different superscript letter(s) indicates significant difference, $P<0.01$ comparing all the groups.

Data are Mean \pm SEM $(\mathrm{n}=6)$

Key: - CP: cyclophosphamide; MESNA: sodium-2-mecaptorethane sulphonate; VA: V. amygdalina. 
Table 2: Effects of V. amygdalina on lipid peroxidation (LPO) induced by CP.

\begin{tabular}{lll}
\hline Treatment & Dose $\mathrm{mg} / \mathrm{kg}$ & LPO \\
\hline CP Alone & 200 & $50.39 \pm 3.52^{\mathrm{b}}$ \\
MESNA+CP & 67 & $37.43 \pm 3.62^{\mathrm{ab}}$ \\
VA + CP & 250 & $22.69 \pm 0.88^{* \mathrm{a}}$ \\
VA Alone & 250 & $21.00 \pm 1.14^{* \mathrm{a}}$ \\
Naïve Control (Normal Saline) & $0.2 \mathrm{ml} / 100 \mathrm{~g}$ & $25.04 \pm 0.61^{* \mathrm{a}}$ \\
\hline
\end{tabular}

One-way ANOVA followed by post-hoc LSD and Duncan was adopted.

$\mathrm{LSD}=$ Means in the same column with asterisks (*) indicate significant different $P<0.01$, compared to $\mathrm{CP}$ treated animals. Duncan= Means in the same column with different superscript letter(s) indicates significant difference, $P<0.01$ comparing all the groups.

Data are Mean \pm SEM $(n=6)$.

Table 3: Effects of $V$. amygdalina on Haematuria induced by CP.

\begin{tabular}{lcc}
\hline Treatment & Dose $\mathrm{mg} / \mathrm{kg}$ & Presence of Haematuria \\
\hline Naïve Control (Normal Saline) & $0.2 \mathrm{ml} / 100 \mathrm{~g}$ & Negative \\
CP Alone & 200 & Positive \\
MESNA+CP & 67 & Negative \\
VA + CP & 250 & Negative \\
VA alone & 250 & Negative \\
\hline
\end{tabular}

Table 4: Effects of $V$. amygdalina on hematological parameters of peripheral blood in CP-induced toxicities

\begin{tabular}{|c|c|c|c|c|c|}
\hline Parameter & $\begin{array}{l}\text { Naïve Control } \\
\text { (Normal Saline) }\end{array}$ & CP Alone & MESNA & $\mathrm{VA}+\mathrm{CP}$ & VA Alone \\
\hline Dose $(\mathrm{mg} / \mathrm{kg})$ & $0.2 \mathrm{ml} / 100 \mathrm{~g}$ & 200 & 67 & 250 & 250 \\
\hline $\begin{array}{l}\text { RBC count } \\
\left(\times 10^{6} \mu \mathrm{l}\right)\end{array}$ & $9.57 \pm 0.24 *^{\mathrm{a}}$ & $3.49 \pm 0.62^{b}$ & $6.97 \pm 0.45 * \mathrm{ac}$ & $9.27 \pm 0.48 *^{\mathrm{a}}$ & $9.81 \pm 0.53 *^{\mathrm{a}}$ \\
\hline $\begin{array}{l}\text { WBC count } \\
\left(\mathrm{x} 10^{3} \mu 1\right)\end{array}$ & $12.02 \pm 0.76^{*^{\mathrm{a}}}$ & $3.17 \pm 0.27^{\mathrm{b}}$ & $6.94 \pm 0.57 * \mathrm{c}$ & $11.42 \pm 0.59 *^{\mathrm{a}}$ & $10.29 \pm 0.61 *^{\mathrm{a}}$ \\
\hline Neutrophil & $2.86 \pm 0.22 *^{\mathrm{a}}$ & $0.17 \pm 0.07^{b}$ & $1.37 \pm .33^{b c}$ & $2.60 \pm 0.32 *^{a}$ & $2.70 \pm 0.43 *^{\mathrm{a}}$ \\
\hline Lymphocyte & $8.38 \pm 0.37 *^{\mathrm{a}}$ & $1.50 \pm 0.24^{b}$ & $5.72 \pm 0.91 *^{\mathrm{ac}}$ & $7.72 \pm 0.42 * \mathrm{a}$ & $8.92 \pm 0.47 *^{\mathrm{a}}$ \\
\hline Platelet & $803.00 \pm 62.32 *^{\mathrm{a}}$ & $221.20 \pm 71.44^{b}$ & $725.60 \pm 46.39 *^{a}$ & $787.20 \pm 56.17 * \mathrm{a}$ & $813.80 \pm 38.38 *^{\mathrm{a}}$ \\
\hline Basophil & $0.05 \pm 0.00 *^{\mathrm{a}}$ & $0.03 \pm 0.00 * \mathrm{a}$ & $0.04 \pm 0.00 * \mathrm{a}$ & $0.03 \pm 0.01 * \mathrm{a}$ & $0.03 \pm 0.01 *^{\mathrm{a}}$ \\
\hline Eosinophil & $0.25 \pm 0.03 * \mathrm{a}$ & $0.23 \pm 0.02 * \mathrm{a}$ & $0.24 \pm 0.04 *^{\mathrm{a}}$ & $0.29 \pm 0.07 * \mathrm{a}$ & $0.28 \pm 0.04 * \mathrm{a}$ \\
\hline
\end{tabular}

Data are Mean \pm SEM $(n=5)$. One-way ANOVA followed by post-hoc LSD and Duncan was adopted.

$\mathrm{LSD}=$ Means in the same column with asterisks $(*)$ indicate significant different $P<0.01$, compared to $\mathrm{CP}$ treated animals.

Duncan= Means in the same column with different superscript letter(s) indicates significant difference, $P<0.01$ comparing all the groups. 


\subsection{Histopathological Studies}

\subsubsection{Kidney}

The photomicrograph showed intact renal corpuscles of the kidney and tubules of the control animal (Fig. 1A) unlike those of the animals that received only CP (Fig. 2A). The kidney of the animals that received only $\mathrm{CP}$ presented with mild cellularity and congestion of the glomerulus. MESNA+CP animals (Fig. 3A) presented mild congestion of the glomerulus which is comparable to those that received $\mathrm{CP}$ alone. However, photomicrograph of kidney of animals that received $250 \mathrm{mg} / \mathrm{kg} \mathrm{VA}+\mathrm{CP}$ (Fig. 4A) and $250 \mathrm{mg} / \mathrm{kg} \mathrm{VA}$ alone (Fig. 5A) depicted intact tubules and glomerular tufts with no observable histological changes as seen in normal group that received only saline.

3.4.2 Liver: Histopathological sections of the liver of the control animal showed normal plates of hepatocytes separated by sinusoids (Fig. 1B) unlike those of test animals that received only CP. The liver tissue of the animals that received only $\mathrm{CP}$ in presented with apoptotic cells (Fig. 2B). Liver photomicrographs of animals that received MESNA+CP (Fig. 3B), $250 \mathrm{mg} / \mathrm{kg}$ VA+CP (Fig. 4B), 250mg/kg VA alone (Fig. 5B) were presented with normal plates of hepatocytes with no observable histological change comparable to normal group that received only saline without any treatment.
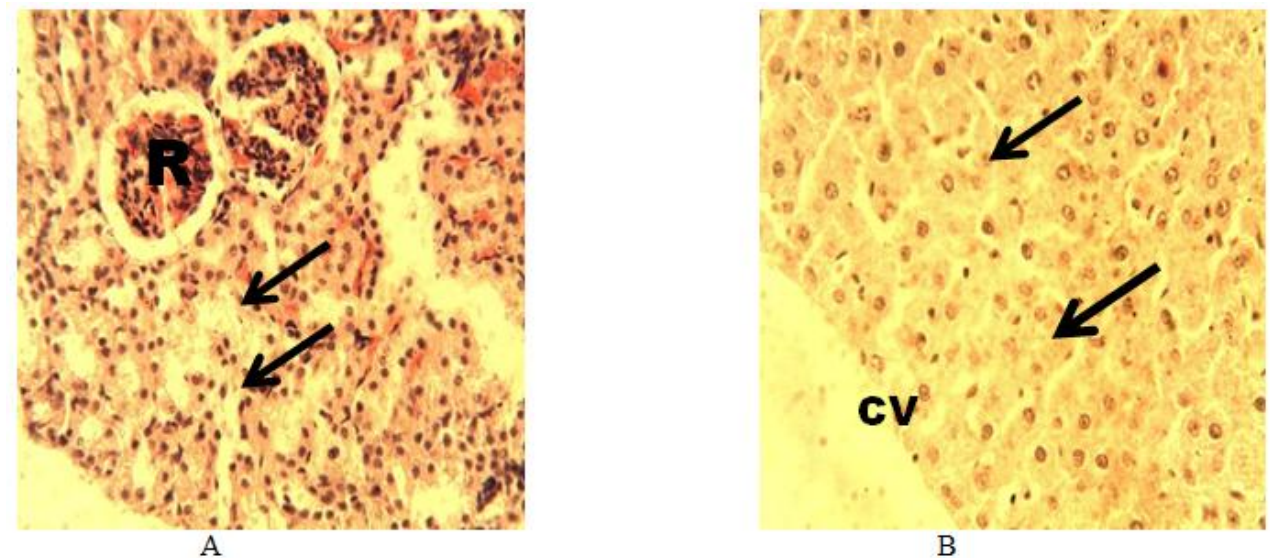

Figure 1: Photomicograph of organ sections from control rats given normal saline showing: A - the kidney showing normal renal corpuscules $(R)$ and tubules (dark arrow); B - the liver showing the central vein (CV) and normal plates of hepatocytes separated by the sinusoids (arrow).
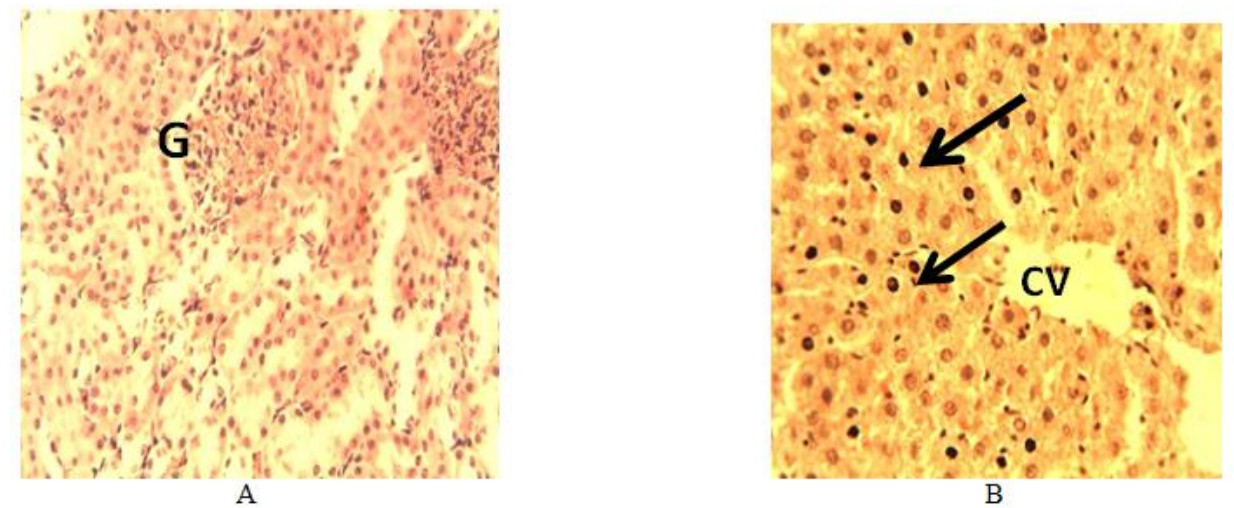

Figure 2: Photomicrograph of sections of organs from rats given 200mg/kg of CP showing: A- Kidney showing mild congestion of the glomerulus(G), B- Liver showing the central vein $(\mathrm{CV})$ and apoptotic cells (arrow). H\&E $\times 400$ 

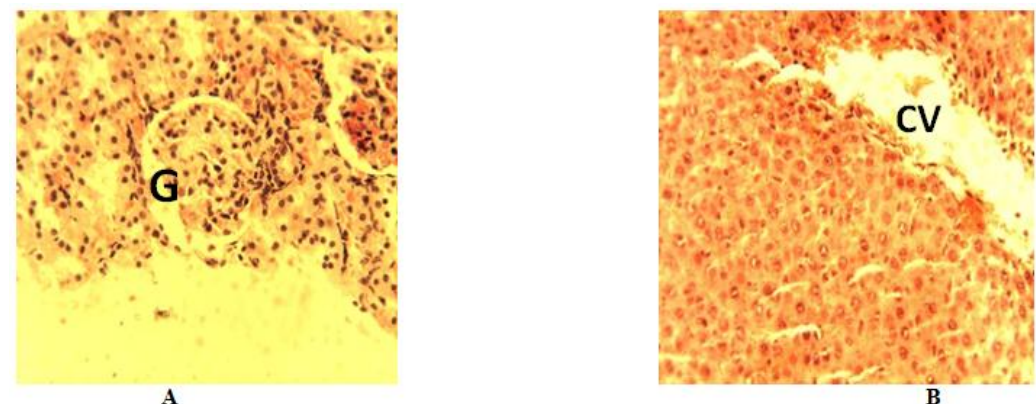

Figure 3: Histologic sections of organs from rats treated with $67 \mathrm{mg} / \mathrm{kg}$ of MESNA and $200 \mathrm{mg} / \mathrm{kg}$ of CP showing: A- kidney showing mild cellularity of the glomerulus(G); B-liver showing central vein $(C V)$ and normal hepatocytes. H\&E $\times 400$.
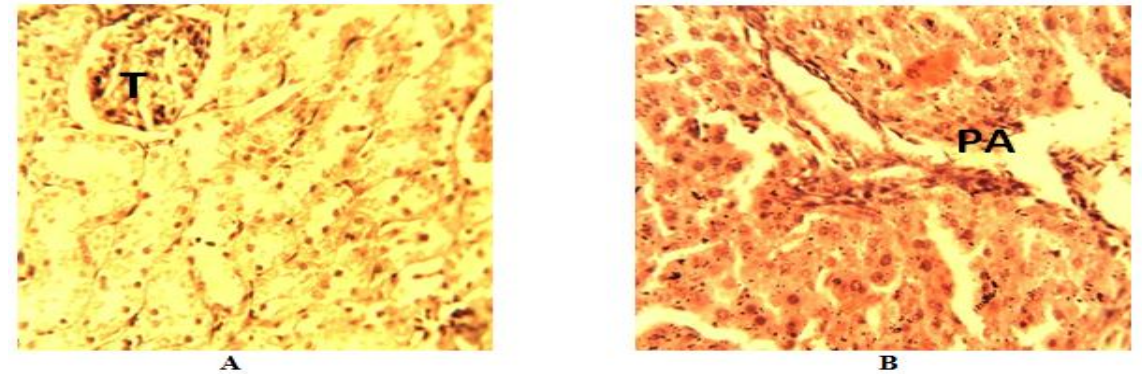

Fig.4. Photomicrograph of sections of organs from rats treated with $250 \mathrm{mg} / \mathrm{kg}$ of $\mathrm{VA}$ and $200 \mathrm{mg} / \mathrm{kg}$ of CP showing: A- kidney with normal tubules and glomerular tufts (T); B-liver showing the portal area (PA). H\&E $\times 400$.
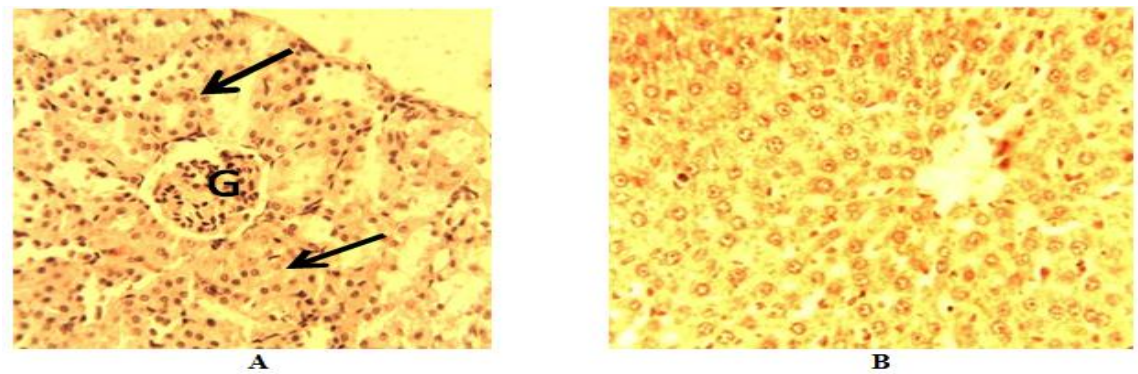

Figure 5: Photomicrograph of sections of organs from rats given $250 \mathrm{mg} / \mathrm{kg}$ of VA Alone showing: A- the kidney with no observable histologic changes (see the glomerulus (G) and renal tubules 'arrow'), B- liver with decreased nuclear chromatin density of the hepatocytes (arrows).H\&E $\times 400$

\section{5.DISCUSSION}

The present study investigated the possible protective and ameliorative potential of $V$. amagdalina in preventing the undesirable myelotoxicity induced by cyclophosphamide in rats.

The use of natural products as alternative medicine has been encouraged especially because they are relatively cheap and with minimal side effects when compared to modern medicine ${ }^{[29]}$.

There is increased demand regarding the scientific proof and justification of the use of herbs for medicinal purpose. Consequently, attempt was made to investigate the protective role of aqueous leaf extracts of $V$. amygdalina against CP-induced myelotoxicity using biochemical, haematological and histological parameters as well as clinical examination.

Myelotoxicity or bone marrow suppression is associated with reduction below normal values of all blood cells which are produced primarily in the bone marrow. Many chemotherpuetic agents including CP have been implicated in short-term damage of the bone marrow which results in abnormally low numbers of leukocytes, erythrocytes and platelets regarded as bone marrow suppression or myelosuppression ${ }^{[30]}$.

In the present study, administration of $\mathrm{CP}$ depleted significantly the essential antioxidants as well as glutathione levels in the serum. There was also reduction below normal values of total leukocyte count (TLC), total erythrocyte count (TEC), platelets, nuetrophils and lymphocytes. Free radical generation is one of the mechanisms by which CP and its derivatives exert their toxic effects in different tissues as well as the bone marrow ${ }^{[31]}$. Again, an overall decrease in the reduced glutathione (GSH) content has often been reported in various tissues as a result of $\mathrm{CP}$ treatment ${ }^{[31-32]}$. 
The CP-induced depletion of GSH is essentially mediated by the interaction of its reactive metabolite, acrolein with GSH

[33]. It is also reported that cysteine which is one of the amino acid constituents of GSH interacts with acrolein in a similar way as GSH itself [33]. Consequently, a number of antioxidants and sulfhydryl (-SH) containing compounds such as sodium-2-mecarptoethane sulphonate (MESNA), amifostine, disulphiram, L-cysteine, N-acetylcysteine, S-carboxy-methyl L - cysteine, D-penicillamine, GSH, glutathione esters etc. have been reported to protect the animals from toxic effects of $\mathrm{CP},{ }^{[34-38]}$. Although several antioxidants have been reported in clinical and experimental studies to offer protection to the kidneys, liver and urinary bladder ${ }^{[10,34]}$, yet more attention has been given to the possible roles of dietary antioxidants in protecting these organs against $\mathrm{CP}$-induced toxicity possibly because they are cheaper and tend to have minimal side effects [9]. Reports on various plant extracts and their phytochemical constituents including flavonoids which are naturally occurring antioxidants that possess pharmacological actions and therapeutic application are still accumulating [39]

The ten (10) days pretreatment with VA completely ameliorated the CP-induced oxidative stress as evidenced by the increased GSH, SOD and catalase with decreased LPO levels comparable to MESNA. There was also sparing of the blood cells indicating protection of the myeloid tissue. Findings on examination of the histopathological slides further authenticates these results as par intact architectural integrity of kidney and liver tissues of the animals that received VA+CP and VA alone compared to those of $\mathrm{CP}$-treated animals which showed active congestion of the capillaries with polymorphonuclear cell infilteration and oedema of lamina propria.

In terms of haematological parameters evaluated, MESNA may not have protected the myeloid system from CPinduced myelosuppression as evidenced by significant $(P<0.01)$ reduction below normal values of all the blood cells, except platelets, basophils and eosinophils.. The animals given MESNA+CP showed high levels of leucopenia, neutropenia and lymphocytopenia. This appears to be in agreement with the report of Berrigan et. al., (1982) ${ }^{[40]}$ who reported that MESNA lacked the ability to protect from CP-induced myelosuppression. In contrast, $V$. amygdalina may have protected the myeloid system from CP-induced myelotoxicity. This may be through another mechanism probably by prevention of lipid peroxidation and nutrient supplementation as earlier reported ${ }^{[41]}$.

$V$. amygdalina has been widely reported to contain high levels of nutrients including proteins with high essential amino acids, carbohydrates and fiber ${ }^{[42-44]}$. The plant has also have been shown to contain appreciable quantities of ascorbic acid and caroteinoids [42-44]. Calcium, iron, potassium, phosphorous, manganese, copper and cobalt have also been found in significant quantities in $V$. amygdalina [42-44]. In addition the phytochemical screening of aqueous leaf extract of $V$. amygdalina has shown that it also contains flavonoids, saponins and sesquiterpene lactones [45-46].

Flavoniods have been widely reported to possess antioxidant activity and are effective scavengers of reactive oxygen species [47]. The molecular mechanism of $V$. amygdalina activity against the CP-induced urotoxicity might have been directly related to its ability to scavenge ROS attributable to flavonoids [47].

\section{CONCLUSION}

The present study investigated for the first time the potential detoxifying efficacy of $V$. amygdalina focusing on its antioxidants activity, reduced LPO and absence of haematuria.

The findings established that $V$. amygdalina is endowed with properties of a detoxifier and adjuvant therapeutic agent for cancer patients. Again considering the fact that MESNA is relatively more expensive and has its own side effects, $V$. amygdalina may be an alternative replacement.

\section{REFERENCES}

[1.] Philips FS, Sternberg SS, Cronin AP, Yidal PM. Cyclophosphamide and urinary bladder toxicity. Cancer Res 1961;21: 15771589

[2.] Colvin M. A review of the pharmacology and clinical use of cyclophosphamide. In: H. M. Pinedo, editor. Clinical Pharmacology of Anti-Neoplastic Drugs. New York: Elsevier/North-Holland Publishing Co; 1978. p. 245-261.

[3.] Friedman OM, Myles A, Colvin M. Cyclophosphamide and related phosphoramide mustards. In: A. Rosowsky, editor. Advances in Cancer Chemotherapy. New York: Marcel Dekker, Inc; 1979. 143-204.

[4.] Carter SK, Livingston R B. Drugs available to treat cancer. In: S. K. Carter, E. Glatstein, and R. D. Livingston (editors). Principles of Cancer Treatment. New York: McGraw-Hill Book Co; 1982. p. 111-145.

[5.] Mirkes PE. Cyclophosphamide teratogenesis. A review Teratogen Carcinogen Mutagen 1985;5: 75-78.

[6.] Fleming RE. An overview of cyclophosphamide and ifosmaide pharmacology. Pharmacotherapy 1997;17: 1465-1475.

[7.] Links M., Lewis C. Chemoprotectans. A review of their clinical pharmacology and therapeutic efficacy. Drugs 1999;57: 293298.

[8.] Abd-Allah AR, Gado AM, Al-Majed AA, Al-Yahya AA, Al-Shabanah OA. Protective effect of taurine against cyclophosphamide-induced urinary bladder toxicity in rats. Clin and Exp Pharmacol and Physio 2005;32: 167-172.

[9.] Łukasz D, Piotr JT. Bladder Urotoxicity Pathophysiology Induced by the Oxazaphosphorine Alkylating Agents and Its Chemoprevention. Postepy Hig Med Dosw (online) 2012;66: 592-602.

[10.] Brock N. The development of MESNA for the inhibition of urotoxic side effects of cyclophosphamide, ifosfamide, and other oxazophosphorine cytostatics. In: G. Mathei and F. M. Muggia, editors. Cancer Chemo- and Immunopharmacology. Berlin; Springer-Verlag; 1980. 274

[11.] Brock N, Pohl J, Stekar J, Scheef W. Studies on the urotoxicity of oxazaphosphorine cytostatics and its prevention--III. Profile of action of sodium 2-mercaptoethane sulfonate. European J of Cancer and Clin Oncol 1982;18 (12): 1377-1387.

[12.] Reinhold-Keller E, Mohr J, Christopher E, Nordmann K, Gross WL. (1992). MESNA side effects with imitate vasculitis. Clin Invest 1992; August 70(8):698-704. 
[13.] Owolabi MA, Jaja SI, Oyekanmi OO, Olatunji O J. Evaluation of the antioxidant activity and lipid peroxidation of the leaves of Vernonia amygdalina. J of Compl and Integr Med, 2008;5(1): ISSN 1550-3840.

[14.] Arhoghro EM, Ekpo, KE, Anosike EO, Ibeh GO. Effect of aqueous extract of bitter leaf (Vernonia amygdalina Del.) on carbon tetrachloride induced liver damage in albino wistar rats. European J of Sci and Res 2009;26: 122-130.

[15.] Asuquo OR, Igiri AO, Akpan JE., Akpaso MI . Cardioprotective potential of Vernonia amygdalina and Ocimum gratissimum against streptozotocin (Stz) - Induced diabetes in wistar rats. The Internet J of Trop Med 2010;7(1) DOI: 10.5580/907.

[16.] Singha, S. C (1966). Medicinal plants in Nigeria. National Press Ltd, Apapa, p. 49.

[17.] Igile, G. O, Oleszek, W., Jurzysta, M, Burda, S, Fanfunso, M, Fasanmade, A. A (1994). Flavonoids from Vernonia amygdalina and their antioxidant activities. Journal of Agricultural Food and Chemistry; 42: 2445-2448.

[18.] Egedigwe, C. A (2010). Effect of dietary incorporation of Vernonia amygdalina and Vernonia colorata on blood lipid profile and relative organ weights in albino rats. MSc., Dissertation, Department of Biochemistry, MOUAU, Nigeria.

[19.] Akah PA, Okafor CL. Blood sugar lowering effect of Vernonia amygdalina Del. in an experimental rabbit model. Phytotherapy Res 1992;6: 171-183.

[20.] Akah, PA, Alemji JA, Salawu OA, Okoye IT, Offiah NV. Effects of Vernonia amygdalina on Biochemical and Hematological Parameters in Diabetic Rats. Asian J of Medical Sci 2009;1(3): 108-3.

[21.] Stone, S. H. (1954). Method for obtaining venous blood from the orbital sinus of a rat or mouse. Science, 119:100-102.

[22.] Riley, V. (1960). Adaptation of orbital bleeding technique to rapid serial blood studies. Proceedings of the Society of Experimental Biology and Medicine, 104: 751-755.

[23.] Sedlak J, Lindsay RH. Estimation of total, protein-bound, and nonprotein sulfhydryl groups in tissue with Ellman's reagent. Ana Biochem 1968;25: 192-195.

[24.] Misra HP, Fridovich I. The role of superoxide anion in the auto-oxidation of epinephrine and a simple assay for superoxide dismutase. J of Biol Chem 1972;247: 3170-3175.

[25.] Magwere T, Naik YS., Hassler JA. Effect of chloroquine treatment on antioxidant enzymes in rat liver and kidney. Free Radical Biol and Med 1997;22:321-7.

[26.] Sinha AK. Colorimetric assay of catalase. Analytical Biochem 1972;47: 389-394.

[27.] Hunter GD, Millson GC, Chandler RL. Observations on the comparative infectivity of cellular fractions derived from homogenates of mouse-scrapie brain. Res in Vet Sci 1963;4: 5439.

[28.] Guttteridge JMC, Wilkins S. Copper-dependent hydroxyl radical damage ascorbic acid: formation of thiobarbituric acid reactive product. Federation of European Biomed Societies: Letters, 1982; p: 327-30.

[29.] Hu X, Sato J, Oshida Y, Yu M, Bajotto G, Sato Y. Effect of Goshajinki-gan (Chinese herbal medicine): Niu-che-sen.qi-wan) on insulin resistance in streptozocin induced diabetic rats. Diab Res in Clin Pract 2003;59: 103-111.

[30.] Friberg, L. E, Henningsson, A, Maas, H, Nguyen, L, and Karlsson, M. O. (2002). Model of chemotherapy-induced myelosuppression with parameter consistency across drugs. Journal of Clinical Oncology 20: 4713-4721.

[31.] Haque R., Bin-Hafeez, B., Parvez, S., Pandey, S., Sayeed, I., Ali M., et al,. Aqueous extract of walnut (Juglans regia L) protects mice against cyclophosphamide-induced biochemical toxicity. Human and Exp Toxicol 2003;22: 473-480.

[32.] Hamrita B, Rouissi K, Soumaya K, Bassem J, Elgaaied A. Do diosgenin ameliorate urinary bladder toxic effect of cyclophosphamide and buthionine sulfoximine in experimental animal models? Afr J of Biotechnol 2012;11(8),2146-2153.

Kehrer, JP, Biswal SS. The molecular effects of acrolein. Toxicol Sci 2000;57: 6-15.

[34.] Habs M, Hebebrand J, Schmahl D. Influence of sulfur-containing compounds on the acute toxicity of cyclophosphamide in male Sprague-Dawley rats. Arzneimittel- Forsch 1984;34: 792-803.

[35.] Davis, L., Kuttan, G. Effect of Withania somnifera on cyclophosphamide-induced urotoxicity. Cancer Letters 2000; 148: 9-

[36.] Bernacki RJ, Bansal S K, Gurtoo HL. Combination of MESNA with cyclophosphamide or adriamycin in the treatment of mice with tumor. Cancer Res 1987;47: 799-802.

[37.] Bhatia K, Kaur M, Atif F, Ali H, Rehman H, Rahman S, et al. Aqueous extract of Trigonella foenum graecum L. ameliorates additive urotoxicity of buthionine sulfoximine and cyclophosphamide in mice. Food Chem and Toxicol 2006a; 44: 1744-1750.

[38.] Bhatia K, Rahman S, Ali M, Raisuddin S. In vitro antioxidant activity of Juglans regia L. bark extract and its protective effect on cyclophosphamide-induced urotoxicity in mice. Redox Report. 2006b;11: 273-279.

[39.] Arhoghro EM, Ikeh C, Uwakwe AA, Ekpo KE, Anosike EO. Curative potential of aqueous extract of leaf (Ocimum gratissimum) on cisplatin induced hepatotoxicity in albino wistar rats. J of Pharmaceut and Sci Innovat 2012;5: (1) 1-8.

[40.] Berrigan MJ, Mannello AJ, Pavelic Z, Williams C J, Struck RF, Hira L. The protective role of thiols in cyclophosphamideinduced urotoxicity and depression of hepatic drug metabolism. Cancer Res 1982;42: 3688-3695.

[41.] Ijeh I, Ejike ECC. Current perspectives on the medicinal potentials of Vernomia amygdalina Del. J of Medicinal Plants Res 2011; 5(7), 1051-1061.

[42.] Udensi EA, Ijeh,II, Ogbonna U. Effect of traditional processing on the phytochemical and nutrient composition of some local Nigerian leafy vegetables. J of Sci and Technol 2002;8: 37-40.

[43.] Ejoh RA, Nkonga DV, Innocent G, Moses MC. Nutritional components of some non-conventional leafy vegetables consumed in Cameroon. Pakistan J of Nutr 2007;6: 712-717.

[44.] Eleyinmi AF, Sporns P, Bressler DC. Nutritional composition of Gongronema latifolium and Vernonia amygdalina. Nutri and Food Sci 2008;38: 99-09.

[45.] Kupchan SM, Hemingway R J, Karim A, Wermer D. Tumour inhibitors XLVII vernodalin and vernomygdin, two new cytotoxic sesquiterpene lactones from Vernonia amygdalina Del. J of Organic Chem 1969;34: 3908-1.

[46.] 46. Jisaka M, Ohigashi H, Takagaki T, Nozaki H, Tada T, Hiroto M, et al,. Bitter steroid glucosides, vernoniosides A1, A2, A3 and related B1 from a possible medicinal plant - Vernonia amygdalina used by wild chimpanzees Tetrahedron 1992;48: 625-632.

[47.] 47. Robak K, Grygleusky RJ. Flavonoids are scavengers of supraoxide anions. Biochem Pharmacol 1988;37: 837-841. 